\title{
Effect of leptin genetic polymorphism on lameness prevalence in Tunisian Holstein cows
}

\author{
Mohamed Amine Ferchichi ${ }^{1}$, Bayrem Jemmali ${ }^{2}$, Sihem Amiri ${ }^{1}$, Abderrahmane Ben Gara ${ }^{2}$, and \\ Boulbaba Rekik ${ }^{2}$ \\ ${ }^{1}$ Institut National Agronomique, 43 Avenue Charles Nicoles 1082, Tunis-Mahrajène, Tunisia \\ ${ }^{2}$ Laboratory of Improvement and Integrated Development of Animal Productivity and Food Resources, \\ Higher School of Agriculture of Mateur, University of Carthage, Tunis, Tunisia
}

Correspondence: Mohamed Amine Ferchichi (med.amine.ferchichi@gmail.com)

Received: 5 April 2018 - Revised: 6 June 2018 - Accepted: 11 July 2018 - Published: 25 July 2018

\begin{abstract}
Lameness is the third most important infection affecting dairy cattle in modern stabling barns. Environmental (food, stables and injuries) and genetic factors are responsible for this pathology. This study aims to investigate the screening of leptin genetic polymorphism and its effect on lameness prevalence. DNA was extracted from 412 blood samples from Holstein cows (lame and healthy). Genotyping was performed by the PCR-RFLP using the Sau3AI restriction enzyme. Prevalence of parity, calving season, age at calving, test-day milk yields, calving year and leptin/Sau3AI genotype was evaluated by the logistics procedure. Results showed that allelic frequencies are 0.68 and 0.32 respectively for the $\mathrm{A}$ and $\mathrm{B}$ allele. Frequencies for the $\mathrm{AA}, \mathrm{AB}$ and BB genotypes are $0.52,032$ and 0.16 respectively. All factors included in the logistic regression model significantly affect the prevalence of lameness in Holstein cows $(P<0.01)$. The probability of lameness incidence varied between $37 \%$ and $99 \%$ respectively for the second and the third parity. The lameness incidence recorded in multiparous is higher than primiparous cows. This recorded incidence is greater in winter and autumn than in the summer and spring. The genetic polymorphism affects the prevalence of lameness in Holstein cows. The incidence of lameness in $\mathrm{AB}$ genotype is lower than that in BB and AA genotype. These results can be a way to improve length of productive life for cattle breeds in Tunisia.
\end{abstract}

\section{Introduction}

Nutritional balance is very important at different physiological stages of dairy cattle. It regulates both anatomicalphysiological and immunological function. Given that, numerous studies have been carried out to explore the relationship between feeding balance and some genotypes. Based on the fact that the incidence of podal pathologies in dairy cows is important during the postpartum period, which is especially deficient in energy, the effect of the lipolytic process seems to be related to the satiety of animals. Leptin is linked to a gene located at chromosome 4. The locus consists of three exons and two introns. Only two exons are translated into the protein. The coding region of the leptin gene is contained in exons 2 and 3, separated by an intron of about $2 \mathrm{~kb}$. The leptin gene promoter extends about $3 \mathrm{~kb}$ (Zadworny and Kuhnlein, 1990).
Leptin is a peptide hormone, has $16 \mathrm{kDa}$ molecular weight, and is synthesized and secreted by adipose tissue cells. It has a globular structure like a hematopoietic cytokine. It is involved in diet, energy balance, fertility and immunity (Fruhbeck et al., 1998; Glaum et al., 1996). It plays an important role in the regulation of dietary intake, energy metabolism, growth and reproduction in cattle (Ramsay and Cranwell, 1999; Choudhary et al., 2005). According to Sharfzadeh and Doosti (2012), leptin has been implicated in the regulation of dietary intake, energy balance, fertility, immune functions and the neuroendocrine axis in rodents, humans and large domestic animals. Leptin plays a key role in the onset of puberty and sexual development (Hoggard et al., 2001), as it stimulates the reproductive system in both sexes, increases the release of luteinizing hormone (LH), and increases hypothalamic gonadotropin hormone $(\mathrm{GnRH})$ (Barash et al., 
1996). As cited by Fitzsimmons et al. (1998) and Haegeman et al. (2000), genetic polymorphisms of bovine leptin gene have an association with fat deposits in beef cattle, feed intake, fetal growth, energy balance, fertility and immune functions.

This study aimed at the screening of leptin genetic polymorphism and its effect on lameness prevalence.

\section{Materials and methods}

\subsection{Sampling}

A total of 412 samples of Holstein cows were taken from farms located in the delegation of Mateur-Bizerte (northeastern Tunisia), belonging to the subhumid bioclimatic stage. This region is one of the basins of dairy cattle in Tunisia. The dairy cattle herd in this region is about 49 thousand cattle, consisting mainly of the Holstein breed.

Sampling was carried out during December-January from 2013 to 2016. The choice of this period is dictated by the incidence of podal diseases during the winter. The sample covered three categories of cows: not lame, lame and cured lame. The identification of the category of the condition was not taken into account because of the lack of the health records.

\subsection{DNA extraction}

The genomic DNA was extracted by a commercial extraction kit (innuPREP Blood DNA mini kit) according to the recommended protocol. The protocol has six essential steps: lysis of blood cells, removal of RNA, DNA binding, washing, ethanol removal and DNA elution. Separation of the DNA using their molecular weight (MW) was performed by electrophoresis on $0.8 \%$ agarose gel.

\subsection{Amplification of the target sequence}

Amplification of the leptin target sequence was carried out using the following primer: $5^{\prime}$ TGGAGTGGCTTGTTATTTTCTTCT-3' and $3^{\prime}$ GTCCCCGCTTCTGGCTACCTAACT- $3^{\prime}$ (Liefers et al., 2002; Javanmard et al., 2003; Joanna, 2011).

The amplification in reaction mixture of a $25 \mu \mathrm{L}$ total volume, which comprises about $200 \mathrm{ng}(4 \mu \mathrm{L})$ of genomic DNA, $0.25 \mu \mathrm{L}$ of the Taq polymerase, $2.5 \mu \mathrm{L}$ of each primer (forward and reverse), $2.5 \mu \mathrm{L}$ of dNTPs, $2 \mu \mathrm{L}$ of $\mathrm{MgCl}_{2}, 7.25 \mu \mathrm{L}$ of free nuclear water and $2.5 \mu \mathrm{L}$ of a buffer solution. PCR steps were as follows: denaturing at $95^{\circ} \mathrm{C}$ for $5 \mathrm{~min}$ then 35 cycles which contain a denaturing step at $94^{\circ} \mathrm{C}$ for $40 \mathrm{~s}$, annealing step at $62^{\circ} \mathrm{C}$ for $40 \mathrm{~s}$ and extending step at $72^{\circ} \mathrm{C}$ for $40 \mathrm{~s}$, and final extending at $72^{\circ} \mathrm{C}$ for $10 \mathrm{~min}$.

\subsection{PCR product digestion (RFLP) gold leptin gene polymorphism}

The Sau3AI restriction enzyme has been used to identify the existing or missing of mutation. PCR products were hydrolyzed in $2.5 \mu \mathrm{L}$ of buffer, $0.2 \mu \mathrm{L}$ of serum albumin bovine (BSA), $12 \mu \mathrm{L}$ of amplifiers (PCR products) and $\mathrm{dH} 2 \mathrm{O}$. In the enzyme restriction digestion technique, BSA is used for the stabilization of some restriction enzymes during DNA digestion and enzyme adhesion to laboratory materials. This mixture was incubated at $37^{\circ} \mathrm{C}$ for $12 \mathrm{~h}$. The digestion products were separated on $2 \%$ agarose gel.

\subsection{Statistical analysis}

Logistic regression (Agresti, 1990) was used to evaluate the importance of $(n)$ independent factors included in the incidence of lameness in dairy cattle. These factors are fixed environmental factors (calving years, 2013-2017); calving season (autumn, winter, spring or summer); calving age, testday milk yields, parity $(1,2$ or 3$)$ and leptin/Sau3AI genotypes (AA, AB and $\mathrm{BB}$ ). The search for significant explanatory variables was done with the logistic regression method by SAS (1989). The $5 \%$ level of significance is considered to identify the important factor explaining the incidence of lameness. $Y$ is a binomial variable whose result is 1 if the animal is lame and 0 if it is healthy:

$Y i=P i(y i=1 \mid X=x i)+e i$,

where $P i$ is the probability of success given a set of independent variables $x i$ and $(1-P i)$ is the probability of failure given the same set of $x i . Y i$ is the binary response variable, and $e i$ values are independent of $E(e i)=0$ and $V(e i j x i)=P i(1-P i)$. Then, logistic regression was used to study the effects of environmental factors, parity and genetic polymorphism of the leptin/Sau3AI gene on the incidence of lameness in dairy cows. The link function that links the probability of having a healthy animal with these various explanatory factors is

$\log \left(\frac{P i(y i=1 \mid X=x i)}{1-P i(y i=1 \mid X=x i)}\right)=\alpha+\sum_{i=1}^{n} \beta i x i$,

where $\alpha$ is the intercept, $\beta i$ is the regression coefficient for $x i, x i$ is the result for the $i$ th explanatory variable and $n$ is the number of explanatory variables.

Calving year and calving age were treated as covariates. The calving season, parity, and genotype of the leptin/Sau3AI gene were converted to binary variables of 1 or 0 . For example, autumn, spring, and winter were given the value 0 if we had awarded the value 1 for the summer.

The chance that a binary response variable leads to success can be described in terms of the chance of this event. In its simplest form, probability is the probability that an event will occur divided by the probability that the same event will not occur. Frequently, the logistic regression model is expressed 


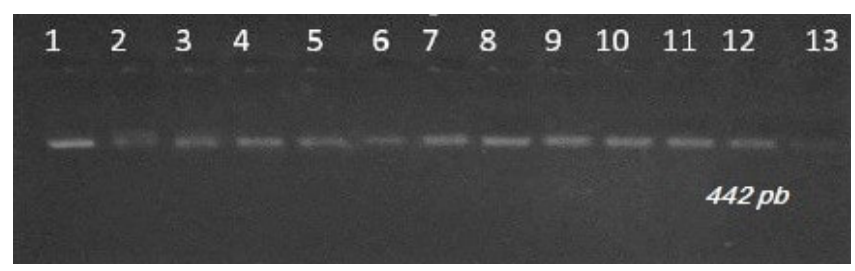

Figure 1. Gel electrophoresis of PCR products of leptin gene in Tunisian cattle. Lane 13: marker molecular weight; 100 bp DNA ladder (Biomatik).

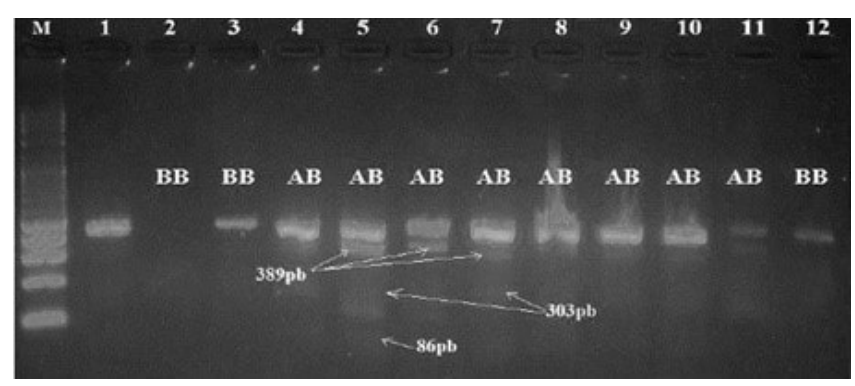

Figure 2. Gel electrophoresis of PCR products after being digested with Sau3AI restriction enzyme for detection of leptin gene polymorphism in Tunisian cattle. Lane M: marker molecular weight 100 bp DNA ladder (Biomatik).

as a ratio of two axis of the products of the pairs of diagonal elements (OR). The probability of incidence of lameness is $(\exp (\beta i))$ times greater when the value of the explanatory variable is increased from $x i$ to $x i+1$. This two-rib ratio provides a measure of the association between the probability of occurrence of the incidence of lameness and the $i$ th explanatory variable. OR is a number between 0 and infinity. An OR $>1$ indicates that the probability of seeing podal pathologies is greater than the probability of having healthy animals. Independence, or absence of association, between the variable $i$ and the incidence of lameness will have $\mathrm{OR}=1$, which is equivalent to $\beta i=0$. OR $<1$ indicates that the probability of incidence of lameness is lower than probability of having healthy animals.

\section{Results}

\subsection{Genotyping}

Visualization of amplifiers (PCR products) under ultraviolet light revealed clear and intense bands of $422 \mathrm{bp}$ on $2 \%$ agarose gel (Fig. 1). The amplified products were digested with Sau3AI enzyme. This endonuclease has two cleavage sites and only the $303 \mathrm{bp}$ bands are visible. The presence of the restriction site indicates the presence of the mutation. Digestion of the PCR products showed bands of $389 / 33$, $303 / 86 / 33$ and $389 / 303 / 86 / 33$ respectively for the animals of genotype AA, BB and $\mathrm{AB}$ (Fig. 2).
Table 1 shows the allelic and the genotypic frequencies. The genotypic frequencies are $0.52,032$ and 0.16 for the AA, $\mathrm{AB}$ and $\mathrm{BB}$ genotypes respectively. The allelic frequencies of the leptin gene are of 0.68 and 0.32 for the A and B allele respectively.

\subsection{Factors affecting the incidence of lameness in Holstein cows}

In this work, the incidence of lame cows is $67.08 \%$. This result recorded on this farm contradicts that of Bouraoui et al. (2014), which showed that podal pathologies have an incidence equal to $38.71 \%$ (score $>2$ ) on the Chergui farm.

All factors included in the step-by-step logistic regression model (parity, calving season, age at calving, test-day milk yields, calving year and leptin/Sau3AI gene polymorphism) significantly affect the prevalence of lameness in Holstein cows.

The incidence of lameness is about $37 \%$ and $99 \%$ for the second and the third parity respectively. We note that the prevalence recorded in multiparous is higher than that recorded in primiparous cows. The incidence of lameness during the winter and autumn is greater than that during the summer and spring. The genetic polymorphism of the leptin/Sau3aI gene affects the prevalence of lameness in Holstein cows. The prevalence of lameness in the $\mathrm{AB}$ genotype is lower than that of the AA and BB genotype.

Age at calving, test-day milk yields, and year of calving significantly affect the prevalence of lameness (Table 2). The incidence of lameness increases by $2 \%$ from one calving year to another.

\section{Discussion}

Diet and energy metabolism are a major factor in the incidence of lameness in dairy cattle. Several studies have reported the association of energy supply with the development of metabolic disorders of the foot (Peterse et al., 1984; Nilson, 1963).

Gourcy (1988) found that all podal pathology appears to be more important on farms where maize silage is more frequently distributed. Espinase (1974) found that diets rich in maize silage favor rumen acidosis and cause hyperhistaminemia which is responsible for acute laminitis. Thierry (2013) confirmed that dairy cows consuming very high-energy rations such as carbohydrates are permanently at the limit of rumen acidosis. Consequently, this situation leads to the absorption of vascular substances, especially at the level of the small blood vessels of the foot. The disruptions of the vasculature cause detachments of the horn of the feet. Then cracks in the hoof appear in which soil bacteria can easily infiltrate and cause abscesses. Brochart (1987) considered that when the average blood glucose exceeds $66 \mathrm{mg} / 100 \mathrm{~mL}$, the risk for metabolic lameness is increased. Metabolic lesions are generally more visible in the hind limbs and have the charac- 
Table 1. Genotypic and allelic frequencies (\%) in the studied gene loci.

\begin{tabular}{lcc|ccc|cc}
\hline Gene locus & Polymorphism & Allele & \multicolumn{2}{|c|}{$\begin{array}{c}\text { Genotypic } \\
\text { frequencies (\%) }\end{array}$} & \multicolumn{2}{|c|}{ Allelic frequencies (\%) } \\
\hline Leptin & A & B & AA & AB & BB & A & B \\
\cline { 2 - 9 } & $C$ & $T$ & 0.52 & 0.32 & 0.16 & 0.68 & 0.32 \\
\hline
\end{tabular}

Table 2. Analysis of maximum likelihood estimates and odds ratio estimates.

\begin{tabular}{|c|c|c|c|c|c|c|}
\hline $\begin{array}{l}\text { Variable } \\
\text { Parity }\end{array}$ & & Coefficient & Odds ratio & \multicolumn{2}{|c|}{$\begin{array}{c}95 \% \text { Wald } \\
\text { confidence limits }\end{array}$} & $P$ value \\
\hline & 1 & Referent & - & - & - & - \\
\hline & 2 & 0.3177 & 1.374 & 1.128 & 1.673 & 0.01 \\
\hline & 3 & 0.6905 & 1.995 & 1.462 & 2.721 & 0.01 \\
\hline \multicolumn{7}{|l|}{ Season } \\
\hline & Autumn & Referent & - & - & - & - \\
\hline & Winter & 0.2512 & 1.286 & 1.075 & 1.538 & 0.01 \\
\hline & Spring & -0.3630 & 0.696 & 0.564 & 0.858 & 0.01 \\
\hline & Summer & -0.1464 & 0.864 & 0.726 & 1.028 & 0.09 \\
\hline \multicolumn{7}{|l|}{ Genotypic } \\
\hline & $\mathrm{AA}$ & Referent & - & - & - & - \\
\hline & $\mathrm{AB}$ & 1.6325 & 0.184 & 0.160 & 0.212 & 0.01 \\
\hline & $\mathrm{BB}$ & 0.6564 & 1.928 & 1.496 & 2.485 & 0.01 \\
\hline Age at calving & & 0.00025 & 1.000 & 1.000 & 1.000 & 0.01 \\
\hline Test-day milk yields & & -0.00098 & 0.999 & 0.999 & 0.999 & 0.01 \\
\hline Calving year & & 0.0211 & 1.021 & 1.018 & 1.024 & 0.01 \\
\hline
\end{tabular}

teristic of being symmetrical. Sansinanea et al. (2001) mentioned the effect of leptin on energy metabolism in cattle from which the idea of studying the leptin gene polymorphism and its prevalence of lameness in dairy cattle comes from.

The genetic polymorphismSau3AI of the leptin gene showed the presence of two alleles (A and B). According to research of Dubey et al. (2008), this gene showed a high genetic variability in Sahiwal Indian cattle.

The allelic frequencies of the leptin gene are 0.68 and 0.32 respectively for the A and $\mathrm{B}$ allele (Table 1). The genotype frequencies are $0.52,032$ and 0.16 respectively for the genotypes $\mathrm{AA}, \mathrm{AB}$ and $\mathrm{BB}$. These frequencies are very similar to those found by Sharifzadeh and Doosti (2012), who confirmed that the frequency of allele $\mathrm{A}$ is greater than that of allele B in cattle in Iran. Sharifzadeh and Doosti (2010) observed three genotypes: AA $(60.71 \%), \mathrm{AB}(37.5 \%)$ and BB $(1.79 \%)$ in the leptin gene polymorphism of Iranian Holstein cattle and suggested that this polymorphism could be further evaluated for marker-assisted selection.

In this study, the multi-variable logistic analysis of parity, calving season, leptin/Sau3AI gene polymorphism, age at calving, test-day milk yields and calving year showed the effect of these factors on the prevalence of lameness in Holstein cows.

The prevalence of lameness increases in multiparous cows. This could be explained by the weight of the animal, and older cows are heavier than heifers and primiparous cows. These results are consistent with those of Espejo et al. (2006) and Sarjokari et al. (2013). Chebel et al. (2008) reported that cows carrying the TT genotype, for leptin gene, had increased incidence of displacement of abomasum (4.3\%), but genotype did not affect the incidence of retained fetal membranes, clinical and subclinical mastitis, or lameness.

The prevalence of lameness is high in winter and autumn. Our study was conducted under the subhumid bioclimatic stage, where rainfall is plentiful and humidity is high. These conditions affect the bedding of stables and promote the development and spread of bacteria, which are responsible for podal pathology. These results agree with those of Rowlands et al. (1983) and Cook (2003), where they found that the frequency of podal pathologies is greater in winter than in summer. Wells et al. (1999) explained the high frequency of lameness incidence by high soil moisture in livestock barns that will soften the horn and decrease wear resistance.

Based on the results of the logistic analysis, the prevalence of lameness is low in individuals of $\mathrm{AB}$ and $\mathrm{AA}$ genotype. 
The highest incidence is recorded in cows with BB genotype. It seems that the $B$ allele increases the incidence of lameness in dairy cows. Allele B was a favorable candidate for 305day dairy breeding programs. HeraviMoussavi et al. (2006) mentioned that the B allele makes it possible to obtain a milk production greater than 305 days without impairing fertility.

\section{Conclusions}

Allelic frequencies for A and B alleles are 0.68 and 0.32 respectively. Genotypic frequency for BB genotype is less than $\mathrm{AA}$ and $\mathrm{AB}$ genotypes. Frequencies for the $\mathrm{AA}, \mathrm{AB}$ and $\mathrm{BB}$ genotypes are $0.52,032$ and 0.16 respectively.

Parity, calving season, age at calving, test-day milk yields, calving year and leptin/Sau3AI genotype significantly affect the prevalence of lameness in Holstein cows $(P<0.01)$.

The probability of lameness prevalence varied between $37 \%$ and $99 \%$ respectively for the second and the third parity. This prevalence in multiparous is higher than primiparous cows.

This recorded prevalence is greater in winter and autumn than in the summer and spring. Genetic polymorphism of leptin is associated with the prevalence of lameness in dairy cows. The genetic polymorphism affects the prevalence of lameness in Holstein cows. The A allele seems to affect the incidence of lameness. The incidence of lameness in $A B$ genotype is lower than that in $\mathrm{BB}$ and $\mathrm{AA}$ genotype. The $\mathrm{AB}$ genotype seems to be more resistant for podal pathologies.

These results can be a way to improve length of productive life for cattle breeds in Tunisia.

Data availability. The data cannot be made publicly available. They are the property of the Livestock and Pasturing Office OEP Tunisia.

Competing interests. The authors declare that they have no conflict of interest.

Acknowledgements. The authors thank the Livestock and Pasturing Office (OEP) and the Agricultural and Development Corporation (Chergui).

Edited by: Steffen Maa

Reviewed by: three anonymous referees

\section{References}

Agresti, A.: Categorical Data Analysis, John Wiley and Sons, New York, 721 pp., 1990.

Barash, I. A., Chung, C. C., Weigle, D. S., Ren, H., Kabigting, E. B., and Kujper, J. L.: Leptin is a metabolic signal to the reproductive system, Endocrinology, 137, 3144-3147, 1996.
Bouraoui, R., Jemmali, B., M'hamdi, N., Ben Mehrez, C., and Rekik, B.: Etude de l'incidence des boiteries et de leurs impacts sur la production laitière des vaches laitières dans le subhumide tunisien, J. New Sci., 9, 7-17, 2014.

Brochart, M.: Foot lameness of the cow, a multifactorial disease. In: Cattle Housing Systems, Lameness and Behaviour, Dorbrecht, Netherlands, Martinus Nijhoff, 159-165, 1987.

Chebel, R. C., Susca, F., and Santos, J. E. T.: Leptin genotype is associated with lactation performance and health of Holstein cows, J. Dairy Sci., 91, 2893-2900, 2008.

Choudhary, R. S., Vaishnav, J. K., and Nehra, R.: Effect of replacing maize with mesquite pods (Prosopisjuliflora) on the performance of broilers, Indian J. Poult. Sci., 40, 124-127, 2005.

Cook, N. B.: Prevalence of lameness among dairy cattle in Wisconsin as a function of housing type and stall surface, J. Am. Vet Med. Assoc., 223, 1324-1328, 2003.

Dubey, P. P., Sharma, A., Gour, D. S., Prashant Jain, A., Mukhopadhyay, C. S., Singh, A., Joshi, B. K., and Kumar, D.: Leptin gene polymorphism in Indian Sahiwal cattle by single strand conformation polymorphism (SSCP), S. Afr. J. Anim. Sci., 38, 131135, 2008.

Espejo, L. A., Endres, M. I., and Salfer, J. A.: Prevalence of lameness in high-producing Holstein cows housed in freestall barns in Minnesota, J. Dairy Sci., 89, 3052-3058, 2006.

Espinase, J.: Les boiteries,fléaux des élevages laitiers, l'élevage bovin., 9 , 39-44, 1974.

Fitzsimmons, C. J., Schmutz, S. M., Bergen, R. D., and Mckinnon, J. J.: A potential association between the BM 1500 microsatellite and fat deposition in beef cattle, Mamm. Genome., 9, 432-434, 1998.

Fruhbeck, G., Jebb, S. A., and Prentice, A. M.: Leptin: physiology and pathophysiology, Clin. Physiol., 18, 399-419, 1998.

Glaum, S. R., Hara, M., Bindokas, V. P., Lee, C. C., Polonsky, K. S., Bell, G. I., and Miller, R.J.: Leptin, the obese gene product, rapidly modulates synaptic transmission in the hypothalamus, Mol. Pharmacol., 50, 230-235, 1996.

Gourcy, E.: Description de profil de ration dans le cadre d'une enquête éco-pathologique, Thèse Doct. Vét, Toulouse, 87 pp., 1988.

Haegeman, A., Van Zeveren, A., and Peelman, L. J.: New mutation in exon 2 of the bovine leptin gene, Anim. Genet., 31, p. 79, 2000.

HeraviMoussavi, A., Ahouei, M., Nassiry, M. R., and Javadmanesh, A.: Association of Leptin Polymorphism with Production, Reproduction and Plasma Glucose Level in Iranian Holstein Cows, Asian-Aust. J. Anim. Sci., 19, 627-631, 2006.

Hoggard, N., Haggarty, P., Thomas, L., and Lea, R. G.: Leptin expression in placental and fetal tissues: Doesleptin have a functional role?, Biochem. Soc. T., 29, 57-63, 2001.

Javanmard, A., Mohammadabadi, M. R., Zarrigabayi, G. E., Gharahedaghi, A. A., Nassiry, M. R., Javadmansh, A., and Asadzadeh, N.: Polymorphism within the intron region of the bovine leptin gene in Iranian Sarabi cattle (Iranian Bostaurus), Russ. J. Genet., 44, 495-497, 2008.

Joanna, R., James, K., Nkoli, E., Peter, M., Elizabeth, A., and Clare, C.: Health Res. Policy Sy., 9, 10 pp., https://doi.org/10.1186/1478-4505-9-43, 2011.

Liefers, S. C., Te Pas, M. F., Veerkamp, R. F., and Van Der, L. T.: Associations between leptin gene polymorphisms and produc- 
tion, live weight, energy balance, feed intake and fertility in Holstein heifers, J. Dairy Sci., 85, 1633-1638, 2002.

Nilson, S. A.: Clinical, morphological and experimental studies of laminitis in cattle, Acta. Vet. Sc., 4, 188-222, 1963.

Petrese, D. J., Korve, S.,Oldenbroek, J. K., and Talmon, F. P.: Relationship between levels of concentrate-feeding and incidence of sole ulcers in dairy cattle, Vet. Rec., 115, 629-630, 1984.

Ramsay, T. G. and Cranwell, P. D.: A review - Leptin: A regulator of feed intake and physiology in swine, Proceeding of the Seventh Biennial Conference of the Australasian Pig Science Association (APSA), 28 November-1 December, Adelaide, Australia, 157-170, 1999.

Rowlands, G. J., Russell, A. M., and Williams, L. A.: Effects of season, herd size, management system and veterinary practice on the lameness incidence in dairy cattle, Vet. Rec., 113, 441-445, 1983.

Sansinanea, A. S., Cerone, S. I., Zonco, I., García, C., and Auza, N.: Serum leptin levels in cattle with different nutritional conditions, Nutr. Res., 21, 1045-1052, 2001.
Sarjokari, K., Kaustell, K. O., Hurme, T., Kivinen, T., Peltoniemi, O. A. T., Saloniemi, H., and Rajala-Schultz, P. J.: Prevalence and risk factors for lameness in insulated free stall barns in Finland, Livest. Sci., 156, 44-52, 2013.

Sharfzadeh, A. and Doosti, A.: Investigation of leptin gene poly- 35 morphism in Iranian native cattle, Bulgarian Journal of Veterinary Medicine, 15, 86-92, 2012.

Sharifzadeh, A. and Doosti, A.: Genetic polymorphism at the leptin gene in Iranian Holstein cattle by PCR-RFLP, Afr. J. Microbiol. Res., 4, 1343-1345, 2010.

Thierry, F.: Les boiteries des bovins, Mémos vétérinaires, Revenu Agricole Conduite et gestion du troupeau, 1, 1-87, 2013.

Wells, S. J., Garber, L. P., and Wagner, B. A.: Papillomatous Digital dermatitis and associated risk factors in US dairy herds, Prev. Vet. Med., 38, 11-24, 1999.

Zadworny, D. and Kuhnlein, V.: The identification of the Kappa Casein genotype in Holstein dairy cattle using Polymerase Chain Reaction, Theor. Appl. Genet., 80, 631-634, 1990. 